\title{
IMIGRAN DAN MASALAH INTEGRASI SOSIAL
}

\author{
Muhammad Fauzan Alamari
}

\begin{abstract}
Immigration has been a part of human history since before the century, and keep continue until today, but the condition of immigrants in recent days make few nations dilemma on how to handle the immigrants and how to integrate into the society. Its not easy for immigrant to adjust in new society since there are pros and contras in which made this circumtances far more complicated. For example in United States of America, Australia, Indonesia and few European states. But in fact eventhough immigranst sometimes give a huge contribution to the host country such as in economy, sports, technology and etc. sometimes it also give an opposite condition, they could give big problems also like oversupply of workers or sometimes criminality.
\end{abstract}

Keywords: Imigrant, Economic, Social Integration.

\section{PENDAHULUAN}

Imigran menurut Kamus Besar Bahasa Indonesia (KBBI 2020) berarti orang yang datang dari negara lain dan tinggal menetap di suatu negara. Fenomena imigran terjadi karena adanya konsep negara yang menggunakan batas wilayah. Imigran sendiri menurut istilah berarti orang yang melakukan imigrasi menuju sebuah negara dimana mereka bukan warga asli negara tersebut (UKRC.org 2020).

Perpindahan manusia telah terjadi dalam kurun waktu yang cukup lama. Ada yang dilakukan atas dasar perdagangan hingga bencana alam. Pada masa sebelum Masehi, terindifikasi adanya perpindahan dari sebuah area ke area yang lainnya di berbagai belahan dunia. Hal ini dibuktikan dengan adanya sebagian persamaan bahasa yang digunakan di beberapa daerah, sebagai bukti adanya migrasi. Selain bahasa terdapat pula 
pengaruh budaya, hal ini menunjukan adanya sebuah kedekatan antara satu daerah dan lainnya. Perpindahan terjadi bisa terjadi secara cepat jika sebelumnya telah ada perpindahan dari tempat asal mereka (imigran) ke tempat yang akan mereka tuju (History World.net 2020).

Perpindahan manusia terjadi tidak hanya melalui keinginan pribadi, tetapi terkadang juga karena keterpaksaan, seperti pemindahan orang Afrika ke Amerika dalam jumlah yang begitu besar untuk dijual menjadi budak. Hal ini mengikuti tren yang sebelumnya terjadi, seperti adanya perdagangan manusia di kerajaan-kerjaan Eropa untuk keperluan perbudakan ataupun pertunjukan (gladiator/circus). Tetapi ada juga yang berpindah atas dasar kehendak pribadi seperti perpindahan orang Irlandia menuju Amerika Serikat (History World.net 2020).

Alasan lain yang paling sering digunakan untuk perpindahan ialah masalah keamanan, sebut saja perpindahan kurang lebih 1 juta orang Yahudi Polandia menuju Israel, dikarenakan keselamatan jiwa mereka terancam dengan adanya perang yang terjadi di tanah Eropa. Alasan ini sering kali ditemukan di berbagai belahan dunia. Masalah keamanan hidup merupakan sebuah hal yang paling mendasar dari manusia, sehingga harganya tidak bisa ditawar sama sekali. Jika perpindahan bisa menghasilkan keamanan, maka hal itu pasti dilakukan tanpa ada tawar menawar (History World.net 2020).

Fenomena imigran saat ini cukup membuat keberadaan mereka diibaratkan pedang bermata dua yang satu sisi dibutuhkan satu sisi tidak diinginkan. Mereka (imigran) bermigrasi karena berbagai alasan, yang paling utama adalah masalah ekonomi dan masalah keamanan. Tidak bisa dipungkiri, banyak negara yang gagal dalam menjamin keamanan diri penduduknya dan juga keberlangsungan ekonomi yang kuat. Sehingga pilihan untuk bermigrasi menjadi satu-satunya jalan yang dapat ditempuh untuk menyelamatkan diri mereka dan juga keluarga tercinta.

Tulisan ini akan menjabarkan fenomena pengintegrasian imigran melalui dua bagian penting, yaitu dinamika integrasi imigran dengan 
masyarakat lokal dan pasca integrasi yang dilakukan dengan masyarakat lokal. Tulisan ini juga mengambil contoh kasus di Amerika Serikat, Australia, Indonesia dan sebagian negara Eropa. Dari fenomena ini maka memunculkan sebuah pertanyaan Mengapa Integrasi Imigran Cenderung Berbeda di berbagai Negara?

Gambar 1.1 Siklus Migrasi Global

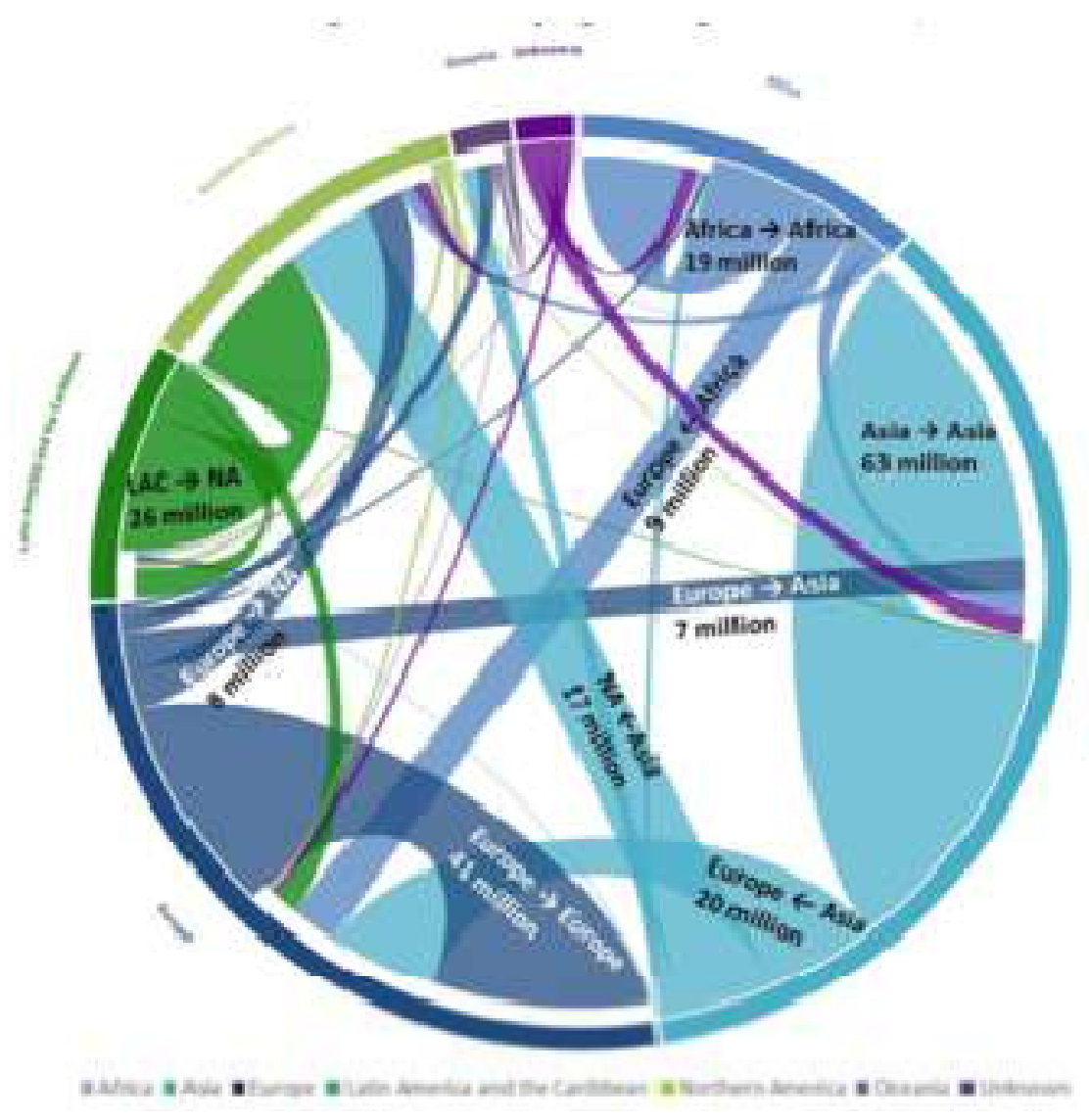

Sumber: UN Report on International Migration, 2017

Notes: NA refers to Northern America, LAC refers to Latin America and the Caribbean

Gambar diatas menunjukan bahwa Asia merupakan benua asal imigran dengan jumlah terbesar. Pada tahun 2017 terdapat 42 juta imigran yang lahir di Asia tetapi menetap di tempat lain. Secara rinci Persatuan Bangsa-Bangsa (PBB) mencatat bahwa terdapat 20 juta imigran di Eropa, 17 juta imigran di Amerika Utara, 3 juta imigran di Pasifik Selatan, dan sisanya tersebar di wilayah lainnya di dunia (United Nations 
Department of Economic and Social Affairs 2017). Kelompok terbesar kedua merupakan imigran dari Amerika Latin dan Karibia yang menyumbang 32 juta orang imigran yang lahir disana tetapi tinggal di tempat lain. Yang mana 26 juta diantaranya menetap di Amerika Utara dan 5 juta di Eropa. Kelompok terbesar terakhir adalah Eropa yang menetap di Amerika Utara sebanyak 8 juta jiwa, Asia 7 juta jiwa dan Pasifik selatan 3 juta jiwa (United Nations Department of Economic and Social Affairs 2017).

Secara global, India menjadi negara dengan persebaran penduduk terbanyak yang menjadi migran internasional. Diikuti oleh Meksiko, Rusia, dan Tiongkok. Pada tahun 201716.6 juta orang dari India hidup di negara lain, lalu diikuti oleh 13 juta orang Meksiko, 10.6 juta orang Rusia, 10 juta orang Tiongkok, 7.5 juta orang Bangladesh, 6.9 juta orang Suriah, 6 juta orang Pakistan dan 5.9 juta orang Ukraina (United Nations Department of Economic and Social Affairs 2017).

Gambar 2. Grafik Total Migran Dunia 2000 \& 2017 


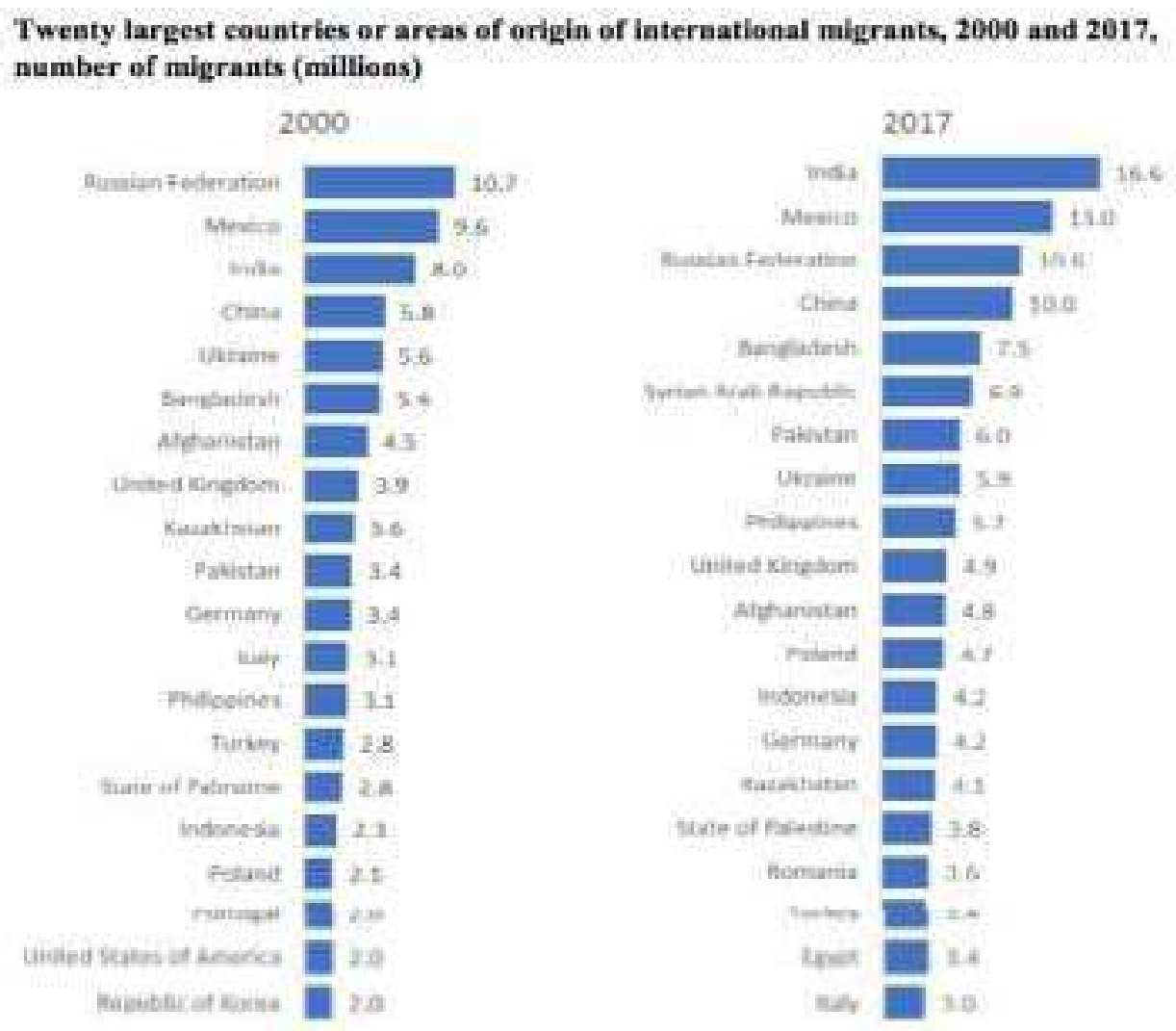

Sumber: UN Report on International Migration, 2017

Bisa dianggap bahwa peningkatan dalam jumlah manusia yang melakukan migrasi dikarenakan adanya kemudahan dalam perpindahan manusia (transportasi) yang menyebabkan meningkatnya jumlah imigran di berbagai negara di belahan dunia.

\section{Konsep integrasi}

Migrasi menuju sebuah negara atau sebuah kota dapat merubah ukuran dan komposisi negara atau masyarakat yang menerima kehadiran imigran. Selanjutnya, imigran harus menyesuaikan diri sebagai seorang pendatang dengan penduduk tetap (indigenous) dan begitu juga dengan sebaliknya. Ilmu sosial dalam hal ini menjelaskan, bahwa dengan adanya fenomena tersebut adanya proses integrasi sangatlah dibutuhkan (Bosswick \& Heckmann 2006).

Integrasi, dalam konteks sosial mengacu kepada kestabilan dan hubungan kerjasama dalam sistem sosial, sehingga integrasi dapat juga 
dilihat sebagai sebuah proses penguatan dalam sistem sosial dengan menerima adanya aktor baru dan grup baru yang akan diperkenalkan dalam sistem. Maka dari itu diperlukan proses integrasi imigran, yang kemudian jika proses ini berhasil, maka masyarakat akan menyatakan mereka (imigran) menjadi satu kesatuan dengan mereka atau terintegrasi (Bosswick \& Heckmann 2006).

Esser mengajukan 4 dasar integrasi sosial: Akulturasi, Penempatan, Interaksi, dan Identifikasi (Esser 2000). Adapun secara rinci keempat aspek dasar tersebut adalah:

1. Akulturasi, aspek ini merujuk kepada proses dimana seorang individu memiliki pengetahuan, budaya, dan kompetensi yang dibutuhkan untuk dapat berinteraksi secara sukses di dalam sebuah masyarakat.

2. Penempatan, aspek ini merujuk kepada kondisi dimana seseorang mendapatkan posisi di masyarakat sebagai pendidik atau masuk dalam sistem ekonomi, atau sebagai seorang warga negara di negara baru yang ia tempati. Penempatan juga merujuk kepada akuisisi hak yang diperlukan untuk tercapainya hubungan budaya, sosial dan ekonomi.

3. Interaksi, aspek ini merujuk kepada proses pembentukan dari hubungan dan jaringan yang diciptakan oleh individu yang memiliki orientasi yang sama. Hal ini termasuk pertemanan, hubungan romantis, pernikahan, atau yang lebih umum sebagai anggota masyarakat.

4. Identifikasi, aspek terakhir ini merujuk kepada proses dimana seseorang melihat dirinya menjadi bagian kolektif dari sebuah komunitas, dalam bentuk kognitif maupun emosional. 
Lebih lanjut dalam keyakinan yang diutarakannya Esser memfokuskan dimensi integrasi sosial di masyarakat dengan membaginya kedalam beberapa bentuk yakni:

1. Integrasi Struktural

Integrasi struktural merupakan tahapan dimana terdapat akuisisi terhadap hak dan akses terhadap posisi didalam institusi yang berada di dalam masyarakat seperti terlibat didalam sistem ekonomi, pasar pekerja, pendidikan, dan lain-lain. Tahapan ini menjadi tahapan mendasar yang menunjukan bahwa individu (dalam hal ini imigran) telah berhasil untuk mendapatkan pengakuan di dalam masyarakat yang lebih luas.

2. Integrasi Budaya

Integrasi budaya merupakan tahapan dimana imigran yang datang hanya dapat mengakui hak dan posisi mereka di dalam masyarakat yang baru hanya jika mereka telah mengakuisisi kompetensi yang dibutuhkan oleh masyarakat tersebut. Hal ini merujuk kepada sikap dan perilaku mereka di dalam tatanan masyarakat baru yang mereka tempati.

Integrasi budaya tidak selamanya berarti para imigran harus melepaskan budaya dari tempat asal mereka. Tetapi menjadi sebuah keuntungan bagi mereka dikarenakan memiliki dua budaya dan dua bahasa yang lebih lanjut dapat menjadi suatu keuntungan bagi mereka dalam mencari peluang.

3. Integrasi Interaksi 
Integrasi Interaksi berarti penerimaan imigran yang berimplikasi kepada integrasi terhadap jaringan sosial, pertemanan, pernikahan, dan keanggotaan di dalam LSM. Di beberapa level, integrasi memerlukan interaksi komunikasi yang lebih kompetitif (Esser 2000).

Integrasi sosial dapat diartikan sebagai sebuah proses penerimaan dan penyatuan para imigran oleh institusi dalam konteks hubungan maupun posisi mereka didalam struktur sosial/masyarakat di negara yang menerima mereka. Integrasi adalah proses interaksi awal antara imigran dan masyarakat di negara penerima sehingga integrasi dapat dianggap sebagai sebuah tahapan dalam proses belajar bagi imigran untuk menerima budaya baru dan mengetahui hak dan kewajiban, mendapatkan akses dalam hal posisi dan juga status sosial, serta membangun hubungan sosial dengan masyarakat setempat (indigenous). Disisi lain bagi masyarakat lokal (indigenous) integrasi berarti memberikan kesempatan yang sama bagi imigran. Dalam hal integrasi, masyarakat lokal memiliki kekuatan dan peran yang lebih kuat atas keberhasilan proses tersebut (Esser 2000). Dengan keberlanjutan kedatangan imigran, integrasi akan menjadi sesuatu yang selalu diperlukan. Kebijakan dan kriteria untuk mencapai kesuksesan integrasi dapat tercapai dengan peleburan di setiap dimensi yang disebutkan sebelumnya.

\section{Metodologi Penelitian}

Penulis menggunakan metode pengumpulan data kuantitatif dengan mengambil materi dari Buku, Jurnal, Surat kabar, website dan laporan terkait yang dapat mendukung penelitian ini.

Penulis mengambil buku karya Esser H. Soziologie dan Spezielle Grundlagen yang berjudul Die Konstruktion der Gesellschaft yang telah 
diterjemahkan kedalam bahasa Inggris untuk menjadi konsep dasar dalam pembuatan penelitian ini. Selain itu, ada buku acuan tambahan karya Bosswick W dan Heckmann F yang berjudul Integration and access to social rights of migrants: The contribution of local and regional authorities. Berikutnya penulis menggunakan laporan tahunan (2017) dari PBB perihal imigrasi. Untuk menunjang semuanya, penulis menambahkan berbagai sumber website berita seperti New York Times, Guardian, Independent, Bloomberg, Refugee Council hingga CNN Indonesia dan juga masih banyak sumber yang kredibel dan dapat dipertanggungjawabkan. Semua website tersebut digunakan untuk membantu menggambarkan dan menjelaskan fenomena yang sedang diteliti.

\section{Pembahasan}

\section{Dinamika Integrasi Imigran di Dunia}

Proses integrasi imigran yang terjadi berbagai belahan dunia berjalan dengan mekanisme yang berbeda-beda hingga dibutuhkan penggambaran lebih mendalam untuk dapat menggambarkan fenomena yang sebenarnya terjadi di wilayah tersebut.

\section{Eropa}

Sasaran para imigran ini tentu saja negara-negara Eropa yang terkenal makmur dan juga sangat aman. Tak ayal mereka bersedia menempuh perjalanan jauh melewati negara demi negara hingga akhirnya harus menyebrangi laut Mediterranean untuk mencapai Italia ataupun Spanyol untuk selanjutnya melanjutkan perjalanan menuju Perancis,

Jerman, Swiss, Denmark, Inggris, ataupun Norwegia. Perjalanan beresiko ini ditempuh untuk menyambung hidup kedepannya. Walaupun nyawa taruhannya, pada tahun 2018 sendiri sebanyak 50.827 imigran menyeberangi Laut Mediterranean melalui pantai Libya. Sampai Juli 2018, kurang lebih 1.443 dari mereka dinyatakan meninggal atau hilang 
di tengah lautan (Openarms.org 2020). Hal ini menjadikan 'beban' terhadap Italia sebagai negara tujuan para Imigran yang menyebrang melalui Libya. Uang 5 miliar Euro harus dikeluarkan pada tahun 2017 untuk 'merawat' Imigran ini sebelum mereka sampai ke tempat tujuannya. Matteo Salvini seorang wakil Perdana Menteri dan juga Menteri Dalam Negeri Italia menyampaikan pandangannya mengenai permasalahan imigran ini. "Saya tidak suka akan fakta dimana 5 juta orang penduduk Italia hidup dalam kemiskinan tetapi kita harus mengeluarkan 5 miliar Euro dalam satu tahun untuk para imigran ini" Kata Matteo Salvini. Disaat yang sama dia juga mengeluarkan statemen "Kami akan memotong anggaran ini dan menggunakannya untuk warga Italia" (Viscusi \& Gualtieri 2018).

Gambar dibawah ini memperlihatkan jumlah imigran yang menyebrang melalui Laut Mediterania dari September 2015 sampai dengan May 2018.

Gambar 3. Angka Total Imigran yang melalui Laut Meditarania

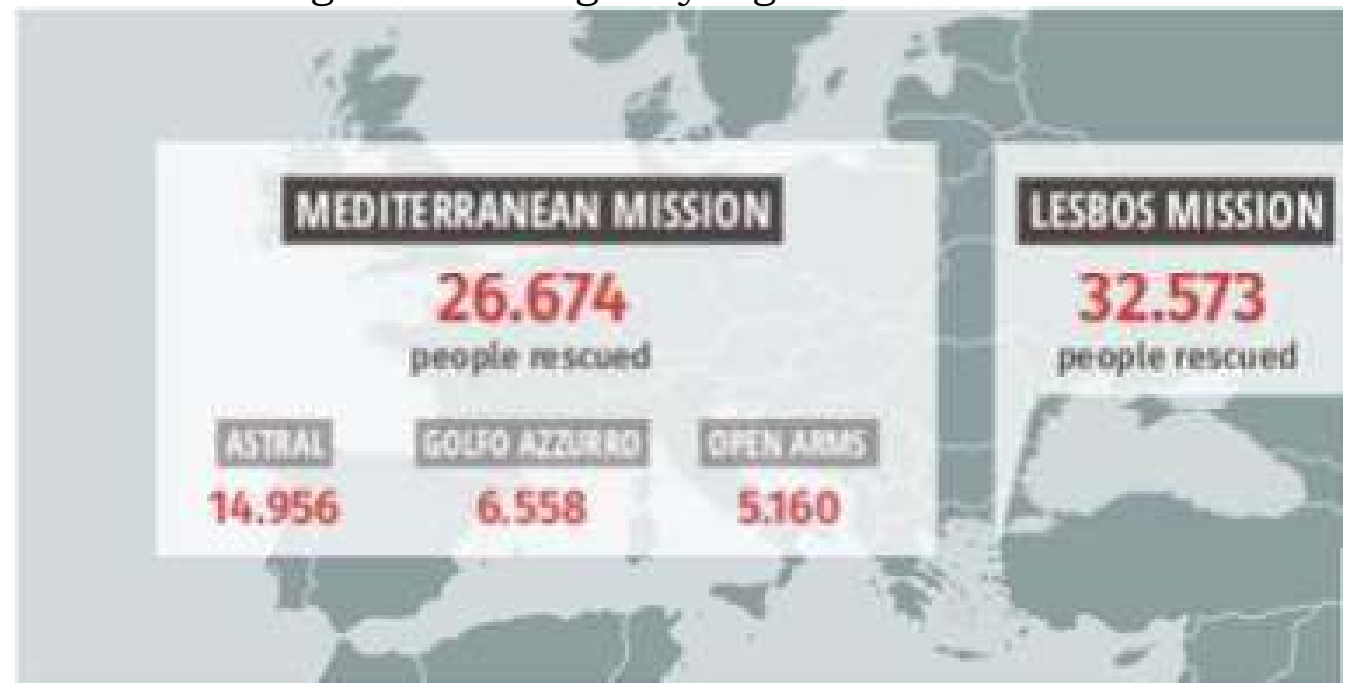

Sumber https://www.proactivaopenarms.org/en/our-missions

Gambar dibawah ini memperlihatkan jalur yang diambil para imigran untuk mencapai negara tujuannya.Dan hampir semua bermula dari laut. 


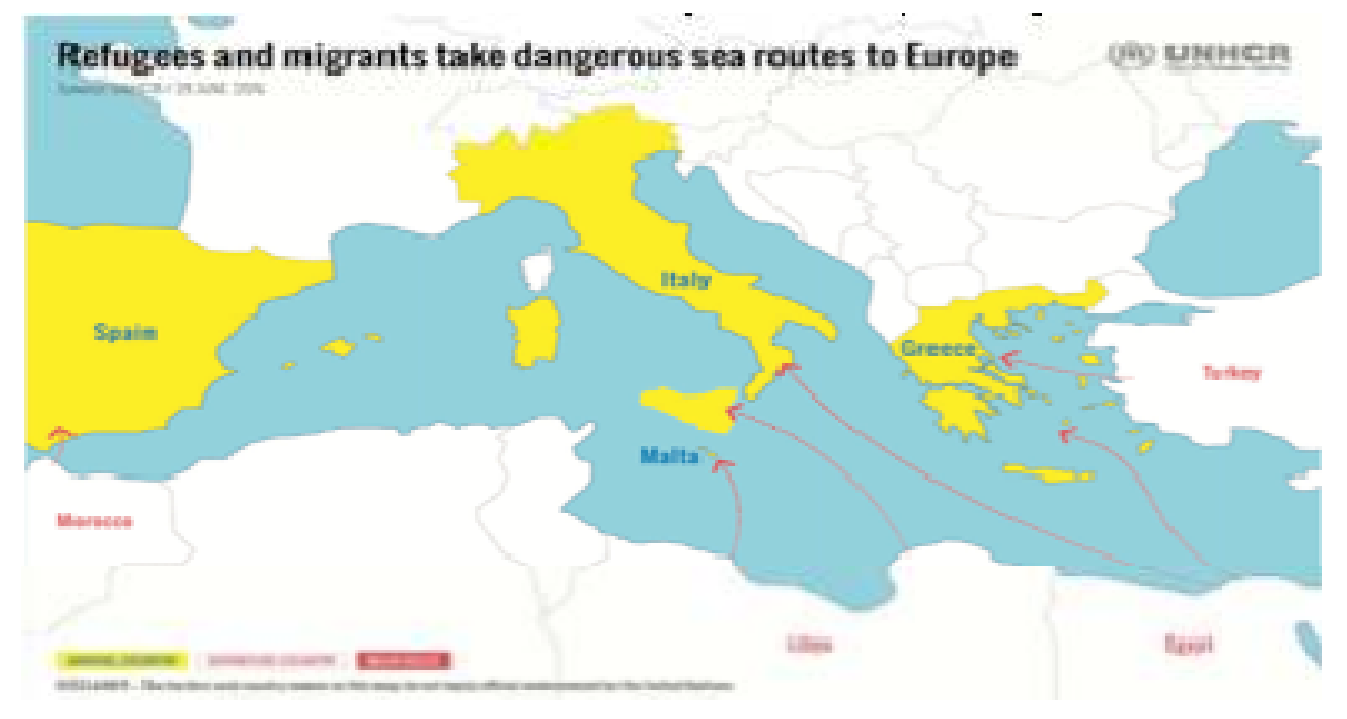

Sumber UNHCR Report $1^{\text {st }}$ July 2015 with title Refugees and migrants take dangerous sea routes to Europe

Hal yang sama terjadi kepada imigran yang melalui jalur darat yang akan menuju Eropa. Negara yang dilewati oleh para imigran ini seperti Yunani, Albania, Serbia, Hungaria, Austria hingga Jerman. Untuk Hungaria sendiri, keberadaan imigran ini dianggap cukup mengganggu sehingga dibangun tembok untuk menghalangi para imigran untuk melewati negara mereka. Hingga hari ini telah terpasang tembok pembatas hingga hampir 161 kilometer antara Hungaria dan Serbia (Rahmat 2020). Hal ini membuktikan jika imigran dianggap sebuah ancaman bagi negara yang mereka lewati. Hal ini juga menuai pro dan kontra dari dalam negeri hingga tingkatan Uni Eropa yang mana Hungaria merupakn anggota dari persekutuan Uni Eropa (Nolan 2015). Dengan adanya persoalan seperti ini membuat para imigran memutar rute melewati laut dan mendarat di Italia. Tapi tentu saja banyak kecelakaan yang terjadi di laut tidak sedikit., yang tercatat sekitar 806 orang pada tahun 2015, 434 orang pada tahun 2016 dan 86 orang pada tahun 2017 yang telah merasakan keganasan laut Aegean (Boztepe 2018). 


\section{Amerika Serikat}

Amerika sebagai negara tujuan utama para imigran di dunia. Menyimpan segudang masalah hari ini. Negara Amerika Serikat sendiri dibangun dari keringat para imigran yang berasal dari Eropa, Asia, Afrika, hingga Amerika Latin. Keberadaan Donald Trump yang mengisi posisi sebagai Presiden Amerika Serikat menimbulkan tensi terhadap imigran meningkat tajam.

Imigrasi memainkan peran penting di dalam sejarah Amerika Serikat. Populasi imigran pada tahun 2014 diperkirakan kurang lebih 42.4 juta jiwa dengan perkiraan Department of Homeland Security ada 1.85 juta imigran yang tidak terdaftar, jadi secara total, diperkirakan 44.25 juta imigran pada tahun 2014. Jika dihitung dengan jumlah imigran pada tahun 1990, maka bisa dikatakan sudah 2 kali lipat, dan 3 kali lipat dari tahun 1980 dan 4 kali lipat sejak tahun 1970 yang berjumlah 9.6 juta imigran yang lahir diluar Amerika Serikat (Camarota \& Zeigler 2016).

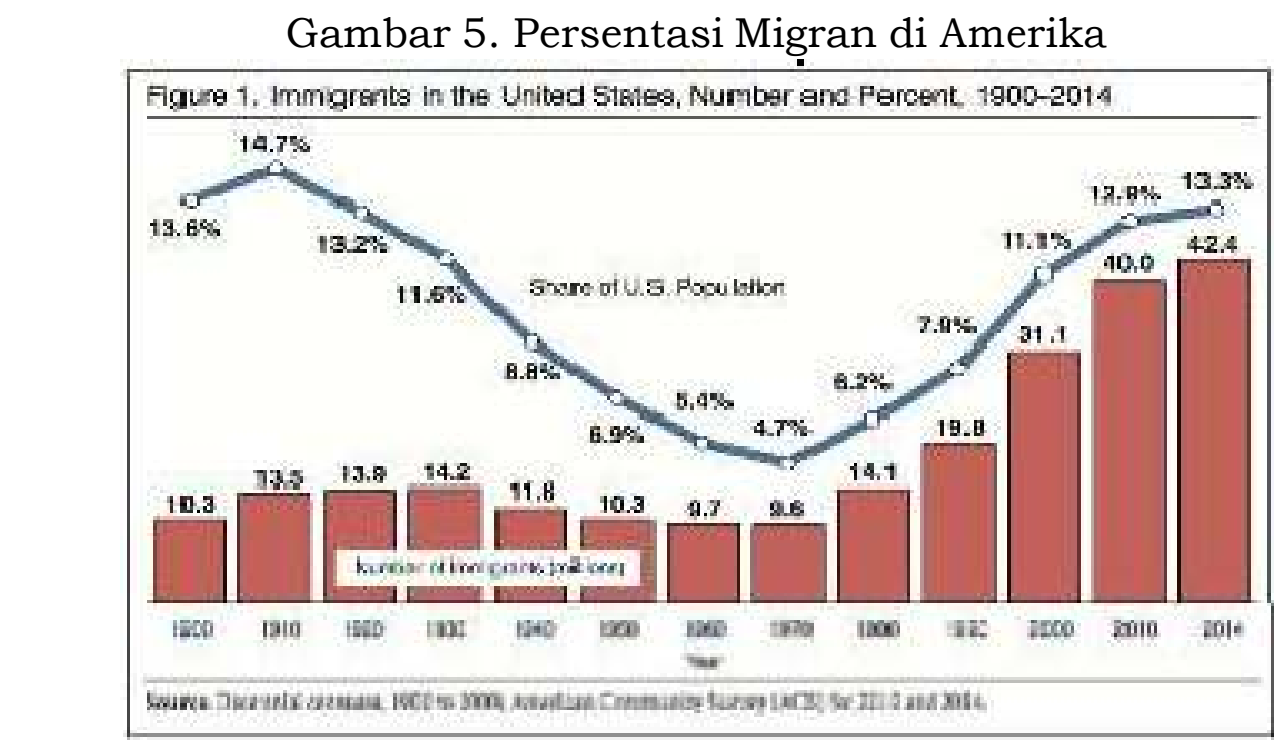

Sumber https:/ / cis.org/sites/cis.org/files/immigrant-profile_0.pdf

Jumlah imigran yang hidup di USA pada tahun 2014 sebanyak 13.3\% dari total penduduk Amerika Serikat, tetapi pada kenyataannya 
terdapat $16.8 \%$ (dari total penduduk AS) yang bekerja dan merupakan imigran. Artinya terdapat kelebihan 5.5\% imigran yang tidak terdata di dalam sensus. Jika dibandingkan dengan penduduk local (native), imigran memiliki tingkat pendidikan yang lebih rendah. Ini menjadikan surplus pekerja di pasar Amerika Serikat. Ini merupakan sebuah masalah baru karena Amerika membutuhkan pekerja berpendidikan yang lebih tinggi dibandingkan imigran yang pada umumnya berpendidikan di bawah SMA (Camarota \& Zeigler 2016).

Gambar 6. Rata-rata Pendidikan Migran

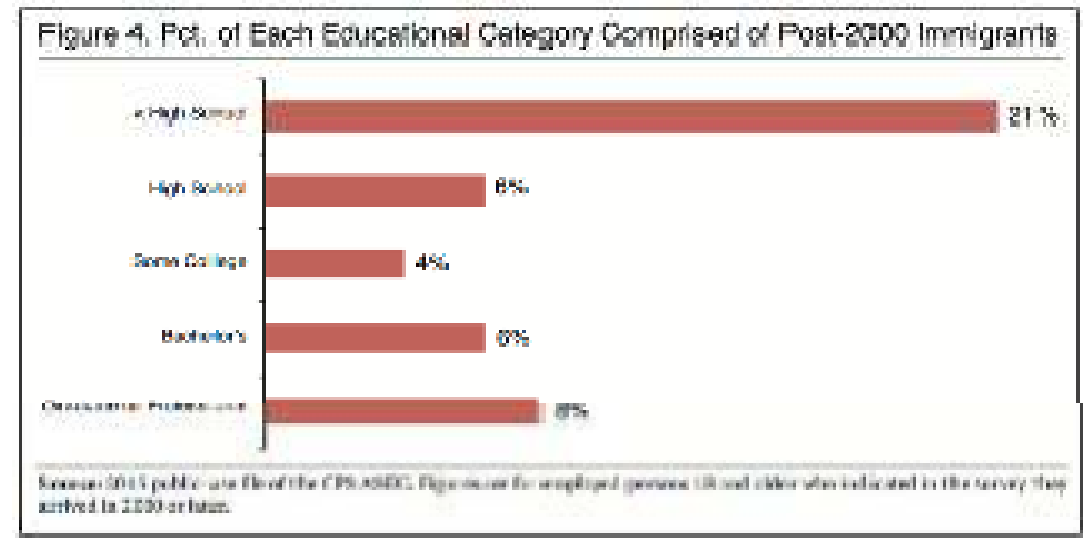

Sumber: https://cis.org/sites/cis.org/files/immigrant-profile_0.pdf

Pada gambar 6, terlihat pendidikan imigran yang datang ke Amerika Serikat pasca tahun 2000 didominasi oleh yang berpendidikan di bawah SMA, hingga $21 \%$ dari jumlah keseluruhan. Hal ini perlu ditingkatkan, karena jumlah lapangan pekerjaan sektor bawah yang sangat terbatas dikarenakan surplus pekerja. Hingga nantinya muncul jumlah pengangguran yang signifikan.

\section{Penanganan Imigran di Era Trump}

Era pemerintahan Trump memiliki pencegahan akan imigran yang begitu besar. Instrumen yang digunakan cukup menarik kontroversi, mulai dari pemisahan keluarga sampai persekusi bagi mereka (imigran) 
yang berusaha untuk pindah ke Amerika Serikat. Di media sosial, Trump mengeluarkan pernyataan (Taub \& Fischer 2018):

"long and complicated legal process," he said on Twitter, "is not the way to go." Instead, he said, "people must simply be stopped at the Border and told they cannot come into the U.S. illegally."

Pemisahan keluarga dilakukan untuk memproses para imigran ilegal yang dianggap criminal ketika melewati perbatasan Amerika Serikat. Data yang dikeluarkan pemerintah Amerika Serikat menunjukan pada bulan April-Mei terdapat pemisahan terhadap 2,000 imigran dengan keluarganya. Menanggapi hal ini jaksa Agung Amerika Serikat, Jeff Sessions berpendapat (White 2018):

"If you are smuggling a child, then we will prosecute you and that child will be separated from you as required by law," Mr Sessions said in announcing the new policy. "If you don't like that, then don't smuggle children over our border."

Imigran di Amerika Serikat berkontribusi sebesar 25\% dari pembentukan perusahaan baru dibidang High-Technology pada periode 2006-2012. Mereka berhasil membukukan penjualan sebesar 63 miliar dollar. Tetapi pada kenyataannya pada bulan April 2017, Trump mengeluarkan slogan "Buy American, Hire American". Pada tahun yang sama Amerika Serikat telah menolak 41 persen aplikasi visa H1-B (visa bagi non-imigran yang diperbolehkan untuk bekerja di bidang khusus dikarenakan memiliki spesialisasi dibidang tertentu, seperti Teknologi, Keuangan, Akuntansi, Riset, Kesehatan dan lain-lain) Ini membuktikan jika Amerika Serikat pada dasarnya menghambat masuknya imigran dari segala sektor yang ada (Lott 2018). 


\section{Australia}

Problematika imigran ini menjadi sebuah isu yang mencuat di halaman depan koran-koran lokal di negara penerima, dikarenakan untuk menerima para imigran ini membutuhkan dana yang tidak sedikit. Australia misalnya, semenjak 2013 membangun rumah detensi di pulau terpencil di Papua Nugini untuk menampung para pencari suaka ini, ribuan orang tidak diperbolehkan masuk ke daratan Australia. Para pencari suaka ini rata-rata sudah menghuni tempat ini hingga 5 tahun lamanya, tak ayal, banyak dari mereka menjadi stress dan terganggu mentalnya (Boochany et al. 2018).

Daniel Webb, Direktur Australia's Human Rights Law Center mengatakan kepada Komisi HAM PBB bahwa jumlah pengungsi di Nauru termasuk 134 anak-anak yang mana 40 orang diantaranya telah lahir disana. Untuk saat ini kurang lebih tersisa 124 anak, dikarenakan beberapa dikirim ke Australia untuk penanganan medis dan beberapa lainnya dikirim ke Amerika Serikat untuk penempatan kembali (MCV.com 2018). Salah seorang pengungsi bernama Abdul (25) yang diwawancarai oleh The Associated Press melalui telepon mengatakan:

"You send people to a place and you want those people to either die or go back to where they came from even if that place is very, very dangerous, The simplest way for me to describe it is it's just like hell" (MCV.com 2018).

Australia secara sadar menawarkan sejumlah uang kepada para imigran untuk kembali ke negara asal mereka, mereka dijanjikan akan diberikan uang senilai $A \$ 25,000$ bagi mereka yang setuju kembali ke rumahnya (tempat asal) (Holmes \& Doherty 2017). Tanpa memperdulikan seberapa besar bahaya yang akan dihadapi oleh para imigran ini ketika kembali ke negara asal mereka. Pemerintah Australia menawarkan untuk 
tetap tinggal di rumah detensi di Papua Nugini atau kembali ke negara mereka. Australia Human Rights Watch, Elaine Pearson mengatakan:

"It would be unthinkable to send any Rohingya back to Myanmar - in the midst of the military's ethnic cleansing campaign against them, Sending them home right now would be a death sentence" (Holmes \& Doherty 2017).

Pemerintah Selandia Baru menawarkan untuk menampung 150 pengungsi yang sedang berada dibawah pengawasan Australia di Barak yang di bangun di Papua Nugini. Tetapi Australia menolak tawaran ini dengan alasan tidak ada jaminan apakah mereka akan kembali ke Australia atau tidak. Pemerintah Australia telah menggelontorkan dana kurang lebih 90 juta Australian Dollar atau setara dengan 68 juta American Dollar untuk mengurusi 1,905 pencari suaka yang sedang berada di Papua Nugini (MCV.com 2018).

\section{Indonesia}

Indonesia pada hari ini pun tidak ubahnya negara destinasi para imigran untuk menyambung hidup, tetapi bedanya Indonesia cenderung menjadi negara transit bagi mereka. Indonesia yang memiliki perbatasan langsung dengan Australia menjadikannya sebagai tempat terdekat untuk mencapai Australia. Imigran yang berada di Indonesia rata-rata merupakan pengungsi korban perang dan pencari suaka yang mana mereka cenderung berasal dari Somalia, Afghanistan, Sudan, hingga Myanmar. Banyak dari mereka yang diselamatkan di perairan bebas ataupun dengan sengaja terbang ke Indonesia. Menurut UNHCR, sampai dengan akhir Maret 2017, tercatat sebanyak 6,191 pencari suaka dan 8,279 pengungsi yang terdaftar di UNHCR Jakarta (Faqir 2018).

Indonesia merupakan salah satu negara yang tidak meratifikasi UN Convention tahun 1951 yang membahas tentang Asylum Seeker dan juga 
Protokol 1967. Atas dasar diatas, Indonesia tidak memiliki kewajiban untuk menampung atau menerima para pengungsi atau pencari suaka. Melainkan tugas UNHCR Indonesia untuk menangani. Tetapi disaat yang sama Indonesia mengalami dilema moral apabila menolak para pencari suaka untuk masuk ke Indonesia atau bahkan mengusir keluar kembali ke negaranya.

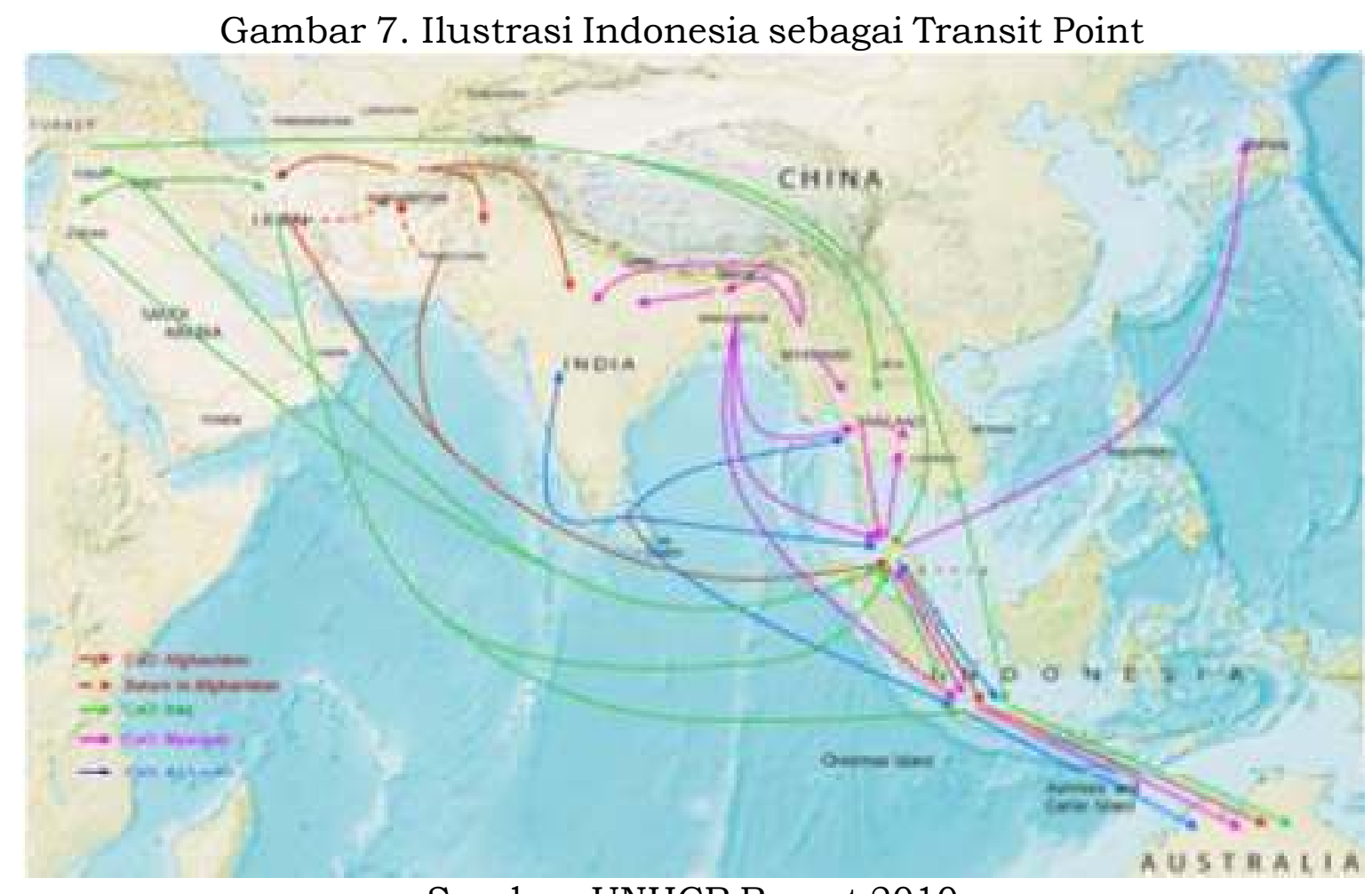

Sumber: UNHCR Report 2010

Gambar di atas menjelaskan tentang alur masuk para pencari suaka atau para imigran dari negara asalnya menuju Australia. Indonesia dijadikan transit point dari berbagai pengungsi dari penjuru negara yang sedang berkonflik, tak ayal Indonesia menampung kurang lebih 11,000 pengungsi. Rata-rata dari mereka ada yang sudah tinggal di Indonesia antara 3-5 tahun untuk mendapatkan bantuan UNHCR untuk tempat penempatan mereka di negara ketiga. Dengan banyaknya imigran ini, Indonesia mendapatkan masalah baru, seperti kekurangan tempat untuk menampung para imigran, dikarenakan jumlah rumah detensi milik Indonesia hanya berjumlah 13 buah, dengan daya tampung terbesar 
mampu menampung 400 orang, ini berlokasi di Tanjung Pinang, Kepulauan Riau. Rata-rata untuk daerah lain berkisar 150-200 orang (Agus 2018).

\section{Imigrasi Sebagai Bagian Dari Dunia}

Proses imigrasi sebenarnya telah terjadi sejak ratusan tahun yang lalu, ditandai oleh perpindahan yang sering dilakukan oleh suku Tartar dari Mongolia yang pada akhirnya mendiami hampir keseluruhan Asia Tengah. Atau juga suku Bugis yang berpindah dengan mengarungi laut hingga Afrika Selatan setelah kejatuhan Kerajaan Makassar ke tangan Belanda (Solihin 2013).

\section{Paska Integrasi}

Kondisi perkembangan teknologi saat ini menjadikan perpindahan manusia menjadi lebih mudah, dan ini membantu para imigran untuk berpindah tempat mencari kerja, pendidikan, peluang dan juga kehidupan yang lebih baik. Disaat yang sama mereka meninggalkan rumah dengan kondisi konflik, kemiskinan, ketidakadilan dan juga lingkungan tempat tinggal yang tidak mendukung hidup mereka. Tetapi jika dilihat after effects yang diberikan oleh para imigran ini, tentu saja sangat menguntungkan. Bisa dilihat dari laporan PBB tentang imigrasi tahun 2017, para imigran pada tahun 2016 berhasil mengirimkan uang sebesar 413 miliar dollar ke kampung halaman (tempat asal). Ini merupakan sebuah jumlah yang luar biasa, efek yang diberikan kepada negara asal sangat membantu perekonomian keluarga mereka yang bisa meningkatkan tingkat pendidikan, ekonomi, kesehatan, taraf hidup, hingga lingkungan tempat tinggal yang lebih baik (UN Report on International 
Mengambil contoh negara Amerika Serikat yang merupakan negara dengan penduduk imigran terbesar di dunia. Keberadaan imigran memberikan kontribusi dalam hal kewirausahaan dan juga inovasi ke dalam perkembangan ekonomi Amerika Serikat. Menurut National Foundation for American Policy Study, dari 87 perusahaan rintisan yang bernilai 1 miliar dollar, terdapat 44 perusahaan yang setidaknya memiliki salah seorang pendirinya yang merupakan imigran. Jika dilihat lebih jauh 44 perusahaan ini jika digabungkan telah memiliki nilai sebesar 168 miliar dollar atau separuh harga dari pasar saham Rusia dan Meksiko. Nilai yang sangat besar untuk sebuah kontribusi. Keberadaan imigran ini sangat memberikan kontribusi terhadap berbagai macam paten yang dibuat, keberadaan imigran sendiri tidak selamanya diisi oleh low class worker tetapi juga high skilled worker. Mereka ini lah yang acapkali berkontribusi kepada inovasi negara dan juga inovasi teknologi. Data dari National Academy of Sciences melaporkan bahwa dari 100 imigran yang bersekolah doctoral, 62 diantaranya berhasil mematenkan karya mereka. Pada akhirnya bisa dikatakan imigran membawa inovasi yang memberikan potensi meningkatkan ekonomi per kapita (Anderson 2016).

Menurut laporan The Small Business Administration (Amerika Serikat) (Anderson 2016):

\begin{abstract}
"Immigrant business owners make significant contributions to business income, generating $\$ 67$ billion of the $\$ 577$ billion in U.S. business income, as estimated from 2000 U.S. Census data," Selanjutnya dilaporkan. "They generate nearly one-quarter of all business income in California - nearly $\$ 20$ billion - and nearly one-fifth of business income in New York, Florida, and New Jersey."
\end{abstract}

Peningkatan angka tenaga kerja menjadi sebuah keuntungan bagi negara yang dituju. Jepang di dalam kasus ini merupakan negara yang 
tidak diuntungkan karena ketiadaan jumlah tenaga kerja imigran yang signifikan. Jepang saat ini mengalami sebuah masalah yang cukup besar dikarenakan angka populasi Jepang yang cenderung memiliki jumlah orang tua yang sangat besar dan juga angka kelahiran yang sangat rendah menjadikan industri Jepang terancam karena tidak adanya regenerasi pekerja. Populasi dengan umur bekerja yaitu 15-64 pada tahun 2015 mencapai 40\% dari keseluruhan populasi Jepang. Sehingga dipercaya akan bertambah 20\% atau bertambah menjadi total 59.78 juta orang pada 2040. Kondisi ini bisa menciptakan penurunan produksi industry di Jepang, dan tentu saja penurunan ekonomi Jepang (Nikkei Asian Review 2017).

Disaat yang sama Amerika Serikat, imigrasi menyediakan jumlah pekerja yang terus meningkat secara signifikan. Keadaan ini membantu Amerika Serikat terhindar dari masalah seperti yang dialami Jepang (penuaan pekerja). Hal ini tentu saja membantu peningkatan GDP atau pendapatan perkapita.

Keberadaan imigran ini sangat memberikan kontribusi terhadap berbagai macam paten yang dibuat, keberadaan imigran sendiri tidak selamanya diisi oleh low class worker tetapi juga high skilled worker. Mereka ini lah yang acapkali berkontribusi kepada inovasi negara dan juga inovasi teknologi. Data dari National Academy of Sciences melaporkan bahwa dari 100 imigran yang bersekolah doctoral, 62 diantaranya berhasil mematenkan karya mereka. Pada akhirnya bisa dikatakan imigran membawa inovasi yang memberikan potensi meningkatkan ekonomi per kapita (Anderson 2016).

Untuk negara penerima sendiri, keuntungan didapat dari kehadiran para imigran yang mengisi sektor low class workers yang terkadang tidak mau diisi oleh penduduk negara tujuan migrasi, dikarenakan standar hidup yang sudah semakin tinggi. Disisi lain, membantu pengembangan 
budaya yang menjadikan negara penerima semakin kaya akan perbedaan budaya (Anderson 2016). Disisi lain, imigran di beberapa negara sangat berkontribusi terhadap dunia olahraga, mulai dari atlet profesional (olimpiade) sampai komersial. Hal ini bisa dibuktikan dengan komposisi pemain tim nasional negara Perancis yang lebih dari setengahnya diisi oleh pemain keturunan imigran. Pada akhir laga mereka di ajang Piala Dunia Sepakbola, mereka berhasil keluar sebagai juara yang menjadikan peran imigran sangat terasa diberbagai sector dimanapun mereka berada (Uduehi 2018).

\section{Kesimpulan}

Imigrasi saat ini menjadi isu yang berkembang pesat pasca berakhirnya perang dunia. Gelombang perpindahan imigran ini menjadi sebuah fenomena yang akhirnya menjadi sebuah tren dikarenakan banyaknya orang yang ingin mendapatkan kehidupan yang baru setelah

peperangan. Pada umumnya, orang dari Eropa Timur akan berpindah ke Eropa Barat untuk mendapatkan penghidupan yang lebih baik. Disamping itu, terdapat banyak orang yang dikirim oleh Hitler ke kamp konsentrasi di berbagai daerah di tanah Eropa.

Imigrasi yang terjadi saat di dunia saat ini merupakan sebuah isu yang sangat besar sehingga diciptakannya kebijakan-kebijakan yang oleh negara-negara di dunia. Hal ini dikarenakan adanya batas negara yang dilewati oleh para imigran, sehingga mereka perlu dilindungi. Hal ini diatur didalam konvensi PBB tahun 1951. Negara yang meratifikasi diwajibkan untuk menjalankan isi yang telah tercantum di dalamnya.

Disamping Amerika Serikat, Eropa Barat yang sering dianggap sebagai bagian dari Eropa yang paling maju, menjadikannya salah satu favorit bagi para imigran sebagai daerah tujuan untuk mencari kerja ataupun perlindungan. Para imigran ini cenderung mengisi kekosongan 
yang ada pada tiap sektor, mulai dari Low class worker, Athlete, hingga High Skilled Worker.

Isu imigran akan selalu menjadi dua sisi koin yang berbeda, yang mana kadand dibutuhkan kadang tidak. Ketika para imigran mengisi pekerjaan di sektor pekerjaan kasar, menunjukan sebuah negara semakin makmur, sehingga warga negara tersebut akan menghindari pekerjaan di sector pekerjaan kasar. Tetapi disaat yang sama, ketika terjadi over population of immigrants ada kecenderungan adanya penolakan yang dilakukan oleh warga setempat. Tak jarang, over supply immigrant mengakibatkan terjadinya kriminalitas dikarenakan susahnya mencari lapangan pekerjaan. Padahal tujuan awal mereka bermigrasi ialah untuk mencari penghidupan, jika pada akhirnya mereka tidak bisa mendapatkannya, maka tentu saja mereka akan menghalalkan segala cara. Sehingga hal ini perlu dicegah oleh negara penerima. Pada akhirnya, masalah imigrasi akan selalu menjadi pedang bermata dua.

\section{DAFTAR PUSTAKA}

Agus, Feri., 2018, Menkumham: Pencari Suaka Jadi Beban Pemerintah, in CNNIndonesia.com, viewed 12/05/20, from https://www.cnnindonesia.com/nasional/20180126153823-20271811/menkumham-pencari-suaka-jadi-beban-pemerintah

Anderson, Stuart., 2016, 3 Reasons Why Immigrants Are Key To Economic Growth, in Forbes.com, viewed 12/05/20, https://www.forbes.com/sites/stuartanderson/2016/10/02/3reasons-why-immigrants-key-to-economic-growth/\#75a487947

Arms, Open., 2020, Our Missions, Open Arms.org, viewed 14/05/20, from https://www.proactivaopenarms.org/en/our-missions

Boochani, Behrouz., Doherty, Ben., \& Evershed, Nick., 2017, Self-harm, suicide and assaults: brutality on Manus revealed, The Guardian.com, viewed 12/05/20, from https://www.theguardian.com/australianews/2017/may/18/self-harm-suicide-and-assaults-brutality-onmanus-revealed 
Bosswick, W. \& Heckmann, F., 2006, Integration and access to social rights of migrants: The contribution of local and regional authorities, Conceptual framework draft, Bamberg.

Bostepe, Mohamad., 2018, Migrant deaths in Aegean Sea plummet 85 pct, in Anadolu Agency.com, viewed 14/05/20, from https://www.aa.com.tr/en/todays-headlines/migrant-deaths-inaegean-sea-plummet-85-pct/ 1021584

Camarota, Steven A \& Zeigler, Karen., 2016, Immigrants in the United States: A profile of the foreign-born using 2014 and 2015 Census Bureau data, CIS.org, viewed 14/05/20 from https://cis.org/sites/cis.org/files/immigrant-profile_0.pdf

Council, Refugee., 2020, Refugee, Refugee Council.org.uk, viewed 1 2/05/20, from https://www.refugeecouncil.org.uk/policy_research/the_truth_about_ asylum/the_facts_about_asylum

Esser, H., Soziologie., 2000, Spezielle Grundlagen. Band 2: Die Konstruktion der Gesellschaft, Campus, Frankfurt-New York.

Faqir, Anisyah Al., 2018, Beda nasib imigran di Indonesia, in Merdeka.com, $\quad$ viewed 12/05/20 from https://www.merdeka.com/khas/beda-nasib-imigran-diindonesia.html

Holmes, Oliver \& Doherty, Ben., 2018, Australia offers to pay Rohingya refugees to return to Myanmar, The Guardian.com, viewed 12/05/20 from https://www.theguardian.com/world/2017/sep/19/australiaoffers-pay-rohingya-refugees-return-myanmar

Lott, Sen Trent., 2018, An immigration policy that is 'America First' still needs to allow immigrants into America, NBC.com, viewed 12/05/20 from https://www.nbcnews.com/think/opinion/immigration-policyamerica-first-still-needs-allow-immigrants-america-ncna901296

My Champalain Valley., 2018, Australia Succeeds in stopping migrants but many in limbo, My Champlain Valley.com, viewed 12/05/20 from https://www.mychamplainvalley.com/news/australia-succeeds-instopping-migrants-but-many-in-limbo/ 1308940082

Nikkei, 2018, Shrinking workforce threatens Japan's economy, in Nikkei Asian Review.com, viewed 12/05/20, from https:/ / asia.nikkei.com/Economy/Shrinking-workforce-threatensJapan-s-economy2

Nolan, Daniel,.., 2015, Hungary orders 100 miles Serbia border fence to keep out migrants, viewed 12/05/20, from https://www.telegraph.co.uk/news/worldnews/europe/hungary/116 
80840/Hungary-orders-100-mile-Serbia-border-fence-to-keep-outmigrants.html

Rahmat, Angga Nurdin., 2020, Realisme Dalam Kebijakan Penolakan Pengungsi Dan Migran Oleh Hungaria Tahun 2015-2018, Vol 5 No 01 (2020): Jurnal Dinamika Global, viewed 01/09/20

Solihin, Lukman., 2013, Mereka Yang Memilih Tinggal Telaah Strategi Adaptasi Mahasiswa Perantau Bugis-Makassar Di Melbourne, Australia., Jurnal Pendidikan dan Kebudayaan, Vol. 19, Nomor 2, Juni 2013, viewed 12/05/20

Taub, Amanda \& Max Fisher., 2018, In U.S. and Europe, Migration Conflict Points to Deeper Political Problems, The New York Times, viewed 16/05/20, from https://www.nytimes.com/2018/06/29/world/europe/us-migrantcrisis.html

Uduehi, Peter., 2018, France's World Cup win stirs debate on antiimmigrant sentiment in Europe, in Now Toronto.com, viewed 12/05/20, from https://nowtoronto.com/news/france-world-cupimmigration/

UN Report on International Migration, 2017

Viscusi, Gregory \& Gualtieri, Thomas., 2018, Italy on Election Alert as Salvini's Permanent Campaign Rolls On, Bloomberg.com, viewed 16/05/20, from https://www.bloomberg.com/news/articles/201807-19/italy-on-election-alert-as-salvini-s-permanent-campaign-rollson

White, Jeremy B., 2018, Immigrant family separations: The reality of USMexico border crisis, Independent.co.uk, viewed 16/05/20 from https://www.independent.co.uk/news/world/americas/uspolitics/border-immigrants-facts-trump-us-mexico-children-familiesseparate-a8406831.html

World, History., 2020, Migrations: from 3000 BC, History World.net, viewed $12 / 05 / 20$, from http://www.historyworld.net/wrldhis/PlainTextHistories.asp?Paragra phID $=\mathrm{bbv}$ 